\title{
REMOVING SMEAR LAYER DURING ENDODONTIC TREATMENT BY DIFFERENT TECHNIOUES - AN IN VITRO STUDY. ACLINICAL CASE - ENDODONTIC TREATMENT WITH ER:YAG LASER
}

\author{
Sharonit Sahar-Helft' ${ }^{1 a^{*}}$, Adam Stabholtz ${ }^{1 \mathrm{~b}}$ \\ 'Department of Endodontics, School of Dental Medicine, Hebrew University - Hadassah, Jerusalem, Israel \\ ${ }^{a} \mathrm{DMD}$ \\ bDMD, Professor
}

Received: October 10, 2016

Revised: October 31, 2016

Accepted: November 21, 2016

Published: November 23, 2016

Cite this article:

Sahar-Helft S, Stabholtz A. Rermoving smear layer during endodontic treatment by different techniques - an in vitro study. A clinical case - Endodontic treatment with Er:YAG Laser. Stoma Edu J. 2016;3(3-4):162-167.

Introduction: Cleaning and shaping the root canal system during endodontic treatment produces a smear layer and hard tissue debris. Removing smear layer through irrigation is a critical adjunct.

Objectives: The aim of this study was $^{1}$ to evaluate in vitro the effect of irrigation techniques, irrigation with syringe-needle and laser-activated irrigation with $17 \%$ EDTA in root canals and ${ }^{2}$ to demonstrate the effect of laser activated irrigation in a patient case.

Materials and Methods: Sixty extracted teeth were divided into three equal groups; Group 1: treated only with ProTaper ${ }^{\mathrm{TM}} \mathrm{F} 3 \mathrm{Ni}$-Ti files. Group 2: positive-pressure irrigation: 17\% EDTA was used for 60-second irrigation, with a syringe. Group 3: Er:YAG laser-activated irrigation with 17\% EDTA irrigation was used for 60 second, Laser flat tip was inserted in the upper coronal third of the root canal.

Results: Scanning electron microscopy showed that the smear layer is removed most efficiently using laser-activated irrigation with a $17 \%$ EDTA.

Conclusion: Smear-layer removal was most effective when the root canals were irrigated using Er:YAG laser at low energy with 17\% EDTA solution. This effect was not observed with the positivepressure techniques. A clinical case demonstrate the effect of using Er:YAG laser activated 17\% EDTA inside root canal.

Keywords: endodontic, root canal irrigants, Er-YAG laser, scanning electron microscope, smear layer.

\section{Introduction}

Root canal treatment is performed to prevent or treat apical periodontitis. Effective endodontic treatment includes cleaning and shaping complex three-dimensional microstructure in which irregular structures such as isthmuses, apical deltas, and lateral canals may be present. The shaping phase aims to enlarge the canal. However creates a smear layer along the root canal walls ${ }^{1}$. The smear layer consists of a superficial layer on the surface of the root canal wall approximately $1-2 \mu$ thick and a deeper layer packed into the dentinal tubules to a depth of up to $40 \mu^{2}$. It contains inorganic and organic substances, including microorganisms and necrotic debris ${ }^{3}$. In addition to the possibility that the smear layer may be infected, it can also protect the bacteria already present in the dentinal tubules by obstructing intra-canal disinfection agents ${ }^{4}$.
Pashley ${ }^{5}$ considered that a smear layer containing bacteria or bacterial products might provide a reservoir of irritants. Thus, complete removal of the smear layer would be consistent with the elimination of irritants from the root canal system ${ }^{6}$. Peters et al. clearly ${ }^{7}$ demonstrated that more than $35 \%$ of the surface area of the canals remained unchanged following instrumentation of the root canal using four $\mathrm{Ni}$-Ti preparation techniques.

Mechanical instrumentation is always combined with irrigation in order to clean the areas that cannot be reached by instruments, to remove the smear layer, and to promote disinfection. Irrigation of the root canal is traditionally performed using a syringe-needle combination. However, the penetration of the irrigant in the apical third is limited ${ }^{8-9}$. Activation of the irrigation solution is suggested to improve their distribution in the canal system and increase irrigation effectiveness. Recent

\section{*Corresponding author:}

Dr.Sharonit Sahar-Helft, Department of Endodontics, School of Dental Medicine, The Hebrew University- Hadassah

P.O. Box 12272, IL-91120 Jerusalem, Israel

tel: 972-2-6777828, fax: 972-2-6778996,e-mail: helft1@bezeqint.net 
advances in dental research have incorporated laser technology as an novel modality for use in endodontic therapy ${ }^{10}$.

In 1917, Albert Einstein wrote: "a special kind of light could be created under the right conditions a light nobody had seen before. The light would be a single color, it would not scatter the way normal light does and it would be very intense". This kind of light would later be called laser. The use of laser at different wavelengths has been proposed to supplement conventional endodontic cleaning procedures ${ }^{11-14}$. Lasers pulsed infrared have been shown to cause cavitation-bubbles and pressure waves within the root canal space when combined with irrigants ${ }^{15-16}$. The cleaning effect of LAl (Laser Activated Irrigation) is based on cavitation: when a pulsed erbium laser is emitting in a root canal brimful of irrigant, strong absorption of the laser energy by the irrigant results in the formation of vapor bubbles at the fiber tip. These vapor bubbles expand during the pulse and then collapse soon after termination of the laser pulse ${ }^{17}$. Erbium lasers are effective in activating irrigating solutions: the absorption coefficients for water at 2,940 nm (Er:YAG laser) and at 2,790 nm (Er;Cr:YSGG laser) are 12,000 and 6,000 respectively ${ }^{18}$ and cause formation of vapor bubbles at the fiber tip. For LAI to be effective, high absorption of laser energy into the irrigating liquid is necessary.

The aim of this study was (1) to evaluate in vitro the effect of irrigation techniques, irrigation with syringe-needle and laser-activated irrigation with $17 \%$ EDTA in root canals and (2) to demonstrate the effect of laser activated irrigation in a ppatient case.

\section{Materials and methods 2.1. Tooth Samples}

Sixty single-rooted human teeth extracted for periodontal reasons were used. (Ethics committee approval, Hadassah Hospital (No 0118-14-HMO). Root canal preparation was carried out using ProTaper ${ }^{\mathrm{TM}}$ (Dentsply Maillefer, Baillaigues, Switzerland) F3 Ni-Ti files with $2.5 \% \mathrm{NaOCl}$ irrigation. The apices of all teeth were sealed with

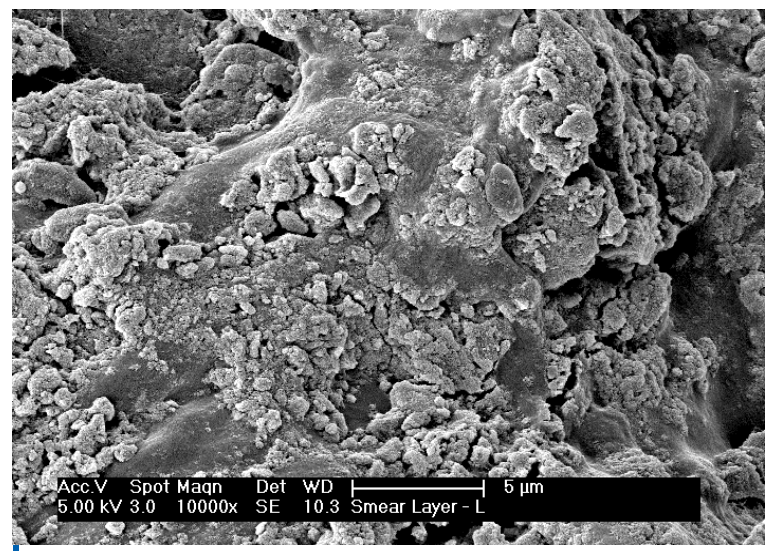

Figure 1. SEM X 10,000 picture presents smear layer after cleaning and shaping the root canal system during endodontic treatment
Super-EBA (Harry J. Bosworth Co., Skokie, IL, USA) to prevent irrigant leakage.

The teeth were randomly divided into three groups. Group 1 was treated with ProTaper ${ }^{\mathrm{TM}}$ F3 Ni-Ti files as described above, and served as a negative control. Group 2 was treated with ProTaper ${ }^{\mathrm{TM}}$ F3 $\mathrm{Ni}-\mathrm{Ti}$ files, at the end of mechanical procedure, root canal was irrigated with $10 \mathrm{ml}$ of $17 \%$ EDTA using a syringe with a $27-\mathrm{G}$ needle (Navitip) for 60 seconds. Group 3 was treated with ProTaper ${ }^{\mathrm{TM}}$ F3 Ni-Ti files, at the end of mechanical procedure, root canal was subjected to LAI with Er:YAG laser at a wavelength of $2940 \mathrm{~nm}$ ( LiteTouch ${ }^{\mathrm{TM}}$, Light Instruments, Yokneam, Israel) equipped with a 17 $\mathrm{mm}$ 400- $\mathrm{mm}$ plan-ended sapphire tip. Radiation was set to $0.5 \mathrm{~W}, 50 \mathrm{~mJ}, 10 \mathrm{HZ}$ for 60 seconds. The water spray of the laser was closed. An irrigation solution of $17 \%$ EDTA was injected during radiation. The laser tip was inserted $3 \mathrm{~mm}$ in the upper coronal third of the root canal.

After the various treatments, two longitudinal cuts were made with a high speed bur and the teeth were split in half.

\subsection{Scanning Electron Microscopy (SEM)}

All samples were dried and mounted on stubs and then coated with Au/Pd using a Polaron SC7640 Sputter Coater (Polaron, Hertfordshire, UK). The effects of the irrigation treatments on the smear layer were examined by SEM at a magnification of 10,000X of the root canal. The samples were examined using FEI Sirion High Resolution SEM and FEI Magellan Ultra-High Resolution SEM (FEl, Eindhoven, The Netherlands).

\section{Results \\ 3.1. Examination of Surface Morphology}

Fig. 1 shows SEM micrographs of the dentin wall at 10,000 magnification of the root canal present smear layer covered the root canal surface after endodontic preparation. In the second group, irrigation with 17\% EDTA through a syringe for 60 seconds removed only part of the smear layer, at the apical part smear layer is present no dental tubules can be seen (Fig. 2).

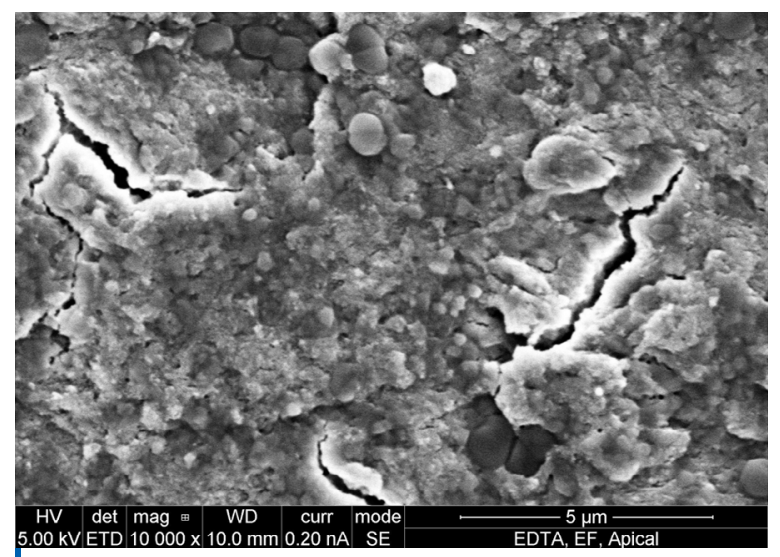

Figure 2. SEM X 10,000 picture presents smear layer at the apical part after irrigation with $10 \mathrm{ml}$ of $17 \%$ EDTA using a syringe for 60 seconds 
In group 3. Er:YAG LAI with 17\% EDTA showed the best smear-layer removal from the entire root canal surface, including apical area with open dentinal tubules (Fig. 3).

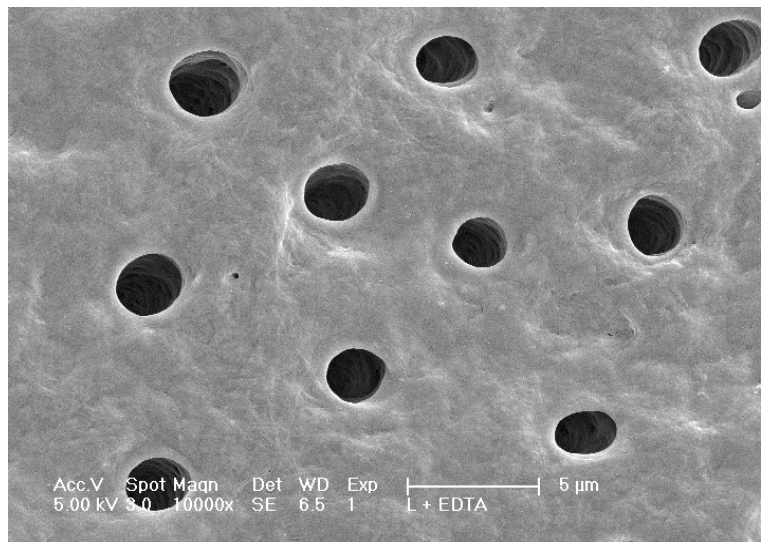

\section{Discussion}

This ex vivo study was designed to evaluate the effectiveness of using a 17\% EDTA irrigation solution with laser irradiation compared to conventional syringe irrigation. Intact teeth were used to simulate the clinical situation as closely as possible. The maximum irrigation time was 1 minute of $10 \mathrm{ml}$ to minimize detrimental effects on the dentin surface. Prolonged application of the EDTA solution might increase $\mathrm{Ca} 2+$ removal from the root dentin. Spangberg ${ }^{25}$ showed that EDTA solution removes the smear layer within 1 minute of reaching the canal surface. In our study, exposure to $17 \%$ EDTA was limited to 1 minute to prevent potential changes in the dentin's microhardness, permeability, and solubility characteristics ${ }^{26}$.

The generation of shockwaves by dental lasers inside the root canals can play an important role in smear layer removal ${ }^{19-24}$. Similarly, smear layer removal can be achieved when water is activated in root canals using erbium lasers (Er,Cr:YSGG or Er:YAG) ${ }^{19,23.24}$, causing the formation of vapor bubbles that expand and implode ${ }^{19,21,22,24}$. Apparently, there is no difference in the efficacy of both wavelengths in terms of smear layer removal In our study we used the laser light here at subablative settings, which does not damage the root canal wall. (we tested before the EDX at this energy ).

The position of the laser tip inside the root canal is important. when using the laser fibers in the root canal, as apical extrusion of the irrigant after laser activation has been described ${ }^{20}$. A previous study by George et al. ${ }^{20}$ showed that there was twice as much dye penetration through the apical constriction with the fiber tip at $4 \mathrm{~mm}$ than at 5 $\mathrm{mm}$. Therefore, in our vitro study, we insert the laser tip at upper part of the root canal, to avoid
The best effect on smear-layer removal and tubules were open in all parts of the canal was present when we used 17\% EDTA with Er:YAG LAI.

Figure 3. SEM $\times 10,000$ picture presents clean root canal wall with open dentinal tubules after Er:YAG laser with 17\% EDTA for 60 seconds

the irrigation extrusion.

The standard irrigation technique during endodontic treatment employs a syringe and needle. Its effectiveness is unpredictable in the apical part of the canal, since the solution is only effective $1.5 \mathrm{~mm}$ beyond the needle tip ${ }^{27,28,31,32}$. The depth of needle penetration depends on the size and morphology of the canal ${ }^{28}$. The results of the present study confirm that 17\% EDTA irrigation with a syringe does not affect the apical segment of the root and the smear layer remains intact on this important part of the root surface.

\section{Conclusion}

Smear-layer removal was most effective when the root canals were irrigated using Er:YAG laser at low energy with $17 \%$ EDTA solution.

\section{A Clinical case - Endodontic treatment with Er: YAG laser}

A clinical case of a male, 42 years old suffers from diabetes .

The clinical examination demonstrated maxillary lateral incisor tooth no 12\# with metal ceramic crown. The sinus - tract was present in the apical area. There was no pain to percussion, pocket depth was normal.

According to the patient story the sinus-tract was there for over 2 years.

The radiographic examination reveled a large radiolocency at the apical part of the lateral incisor tooth. (Fig. 4). The crown was removed and endodontic retreatment was started.

During cleaning and shaping the root canal system with inter-appointment intracanal medicaments such as: Calcium hydroxide, 3 mix (it is mixing of 3 antibiotic: Metronidazole, Minocycline, and Ciprofloxacin), and with Ledermix, the Sinus-tract 

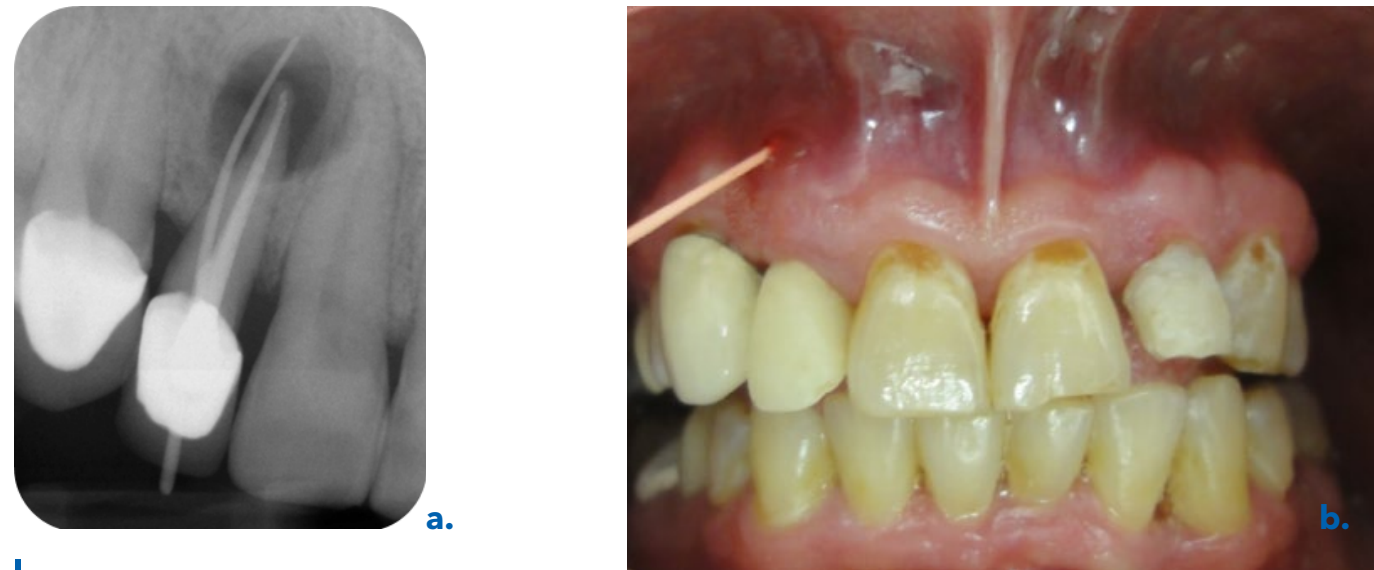

Figure 4. a. Radiograph and b. Photograph demonstrated maxillary lateral incisor tooth \#12 with radiolucency and sinus-tract at the apical area
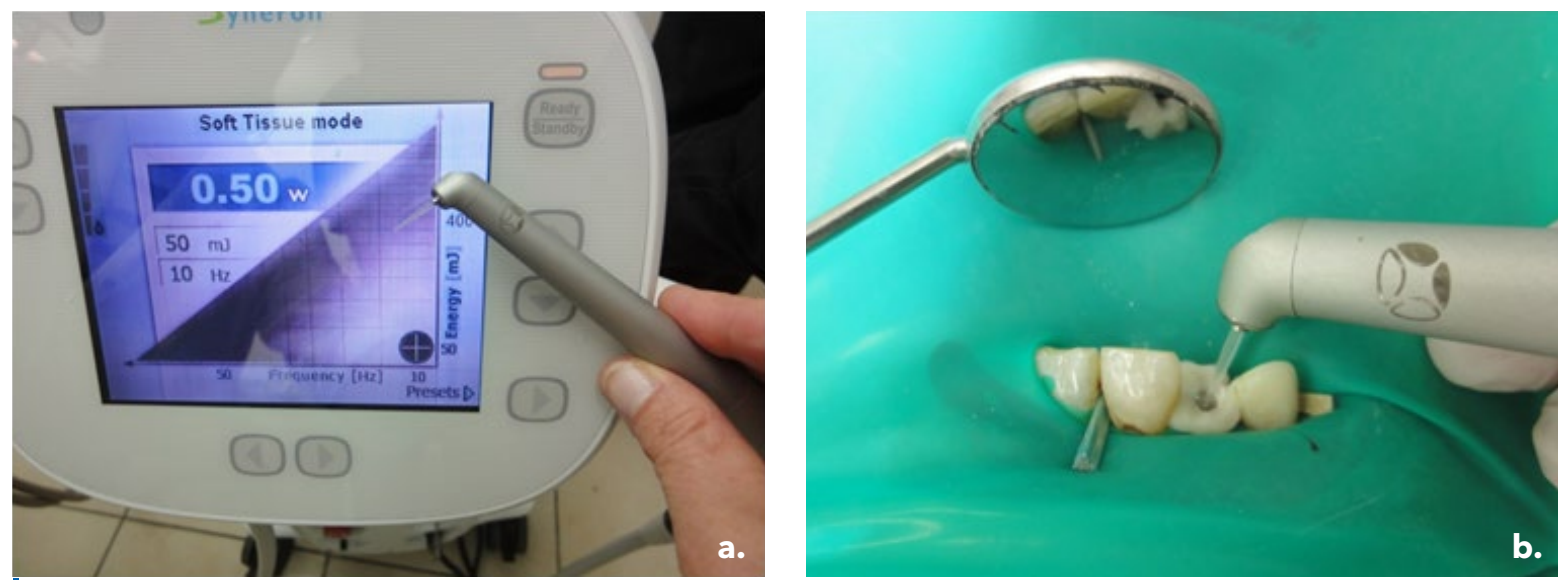

Figure 5. a. LAl with Er:YAG laser. Radiation was set to $0.5 \mathrm{~W}, 50 \mathrm{~mJ}, 10 \mathrm{HZ}$ for 60 seconds.

b. Rubber-dam on tooth \#12 with laser safir tip

persisted. We decided to treat this patient with Laser Activated Irridation, using the Er:YAG laser (LiteTouch ${ }^{\text {TM }}$, Light Instruments, Yokneam, Israel) at energy, $0.5 \mathrm{~W}, 50 \mathrm{~mJ}, 10 \mathrm{HZ}$ for 60 seconds with $17 \%$ EDTA as an irrigation solution. (Fig.5)

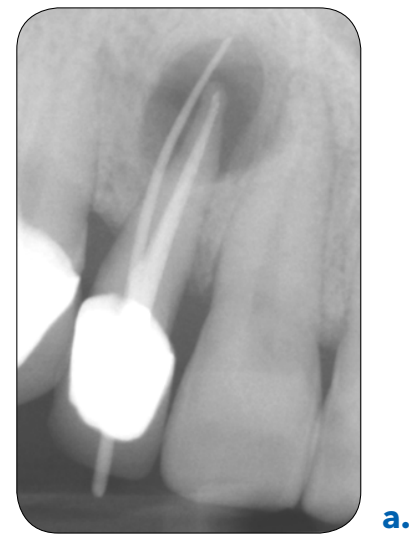

Figure 6. Radiograph tooth \#12

a. Before endodontic treatment, with radiolucency and sinus-tract at the apical area b. 2 years folow up, after LAI with Er:YAG laser

\section{Acknowledgments}

The authors declare no conflict of interest related
The final obturation was accomplished at the same appointment. Approximately 2 years later, the radiograph demonstrates that radiolucency ceased and the periapical tissues heal normally. (Fig. 6) and there is no evidence of the sinus-tract.

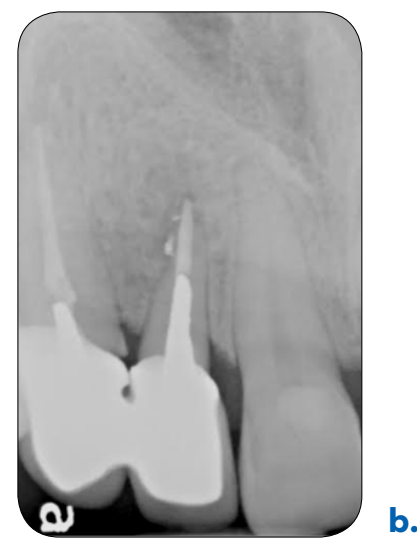

b. 


\section{REFERENCES}

1. Baumgartner JC, Mader CL.A scanning electron microscopic evaluation of four root canal irrigation regimens. J Endod. 1987;13(4):147-157

2. Mader CL, Baumgartner JC, Peters DD. Scanning electron microscopic investigation of the smeared layer on root canal walls. J Endod. 1984;10(10):477-483

3. Torabinejad M, Handysides R, Khademi AA, Bakland LK. Clinical

implications of the smear layer in endodontics: a review. Ora Surg Oral Med Oral Pathol Oral Radiol Endod. 2002;94(6):658666.

4. Haapasalo M, Orstavik D. In vitro infection and disinfection of dentinal tubules. J Dent Res. 1986;66(8):1375-1379.

5. Pashley DH. Smear layer: physiological considerations. Oper Dent Suppl. 1984;3:13-29.

6. Drake DR, Wiemann AH, Rivera EM, Walton RE. Bacterial retention in canal walls in vitro: effect of smear layer. J Endod. 1994:20(2):78-82.

7. Peters OA, Schönenberger K, Laib A. Effects of four Ni-Ti preparation techniques on root canal geometry assessed by micro computed tomography. Int Endod J. 2001:34(3):221-230.

8. Lee SJ, Wu MK, Wesselink PR. The effectiveness of syringe irrigation and ultrasonics to remove debris from simulated ir regularities within prepared root canal walls. Int Endod J. 2004;37(10):672-678

9. Wu MK, Wesselink PR .A primary observation on the preparation and obturation of oval canals. Int Endod J. 2001;34(2):137 141.

10. Green J, Weiss A, Stern A. Lasers and radiofrequency devices in dentistry. Dent Clin North Am. 2011;55(3):585-97, ix-x. doi: 10.1016/j.cden.2011.02.017

11. Kimura Y, Wilder-Smith $P$, Matsumoto K. Lasers in endodontics: a review. Int Endod J 2000;33(3):173-185.

12. Stabholz A, Sahar-Helft S, Moshonov J. Laser in endodontics. Dent Clin North Am. 2004:48(4):809-32, vi.

13. Meire M, De Moor RJG. Lasers in endodontics: laser disinfection, an added value? Endod Pract Today. 2007;1:159-172.

14. De Moor RJG, Torbeyns D, Meire M. Lasers in endodontics. Part 2: root canal wall cleanliness and modification. Endod Pract Today.2009:3:19-33

15. George R, Rutley EB, Walsh LJ .Evaluation of smear layer: a comparison of automated image analysis versus exper observers. J Endod. 2008;34(8):999-1002. doi: 10.1016/j. joen.2008.05.003.

16. Hmud R, Kahler WA, George R, Walsh LJ . Cavitational effects in aqueous endodontic irrigants generated by nearinfrared lasers. J Endod. 2010;36(2):275-278. doi: 10.1016/j. joen.2009.08.012.
17. Blanken J, De Moor RJ, Meire M, Verdaasdonk R. Laser induced explosive vapor and cavitation resulting in effective irri gation of the root canal. Part 1: a visualization study. Lasers Surg Med. 2009;41(7):514-519. doi: 10.1002/lsm.20798.

18. Wieliczka DM, Weng S, Querry MR. Wedge shaped cell for highly absorbent liquids: infrared optical constants of water. Appl Opt. 1989;28(9):1714-1719. doi: 10.1364/AO.28.001714.

19. George R, Walsh LJ. Apical extrusion of root canal irrigants when using Er:YAG and Er, Cr:YSGG lasers with optical fibers: an in vitro dye study. J Endod. 2008;34(6):706-708. doi: 10.1016/j. joen.2008.03.003

20. George R, Meyers IA, Walsh LJ. Laser activation of endodontic irrigants using improved conical laser fiber tips for removing smear in the apical third of the root canal. J Endod. 2008;34(12):1524-1527. doi: 10.1016/j.joen.2008.08.029.

21. Blanken JW, Verdaasdonk RM. Cavitation as a working mechanism of the Er, Cr:YSGG laser in endodontics: a visulatisation study. J Oral Laser Applic. 2007:7:97-106.

22. Blanken J, De Moor RJ, Meire M, Verdaasdonk R. Laser induced explosive vapor and cavitation resulting in effective irrigation of the root canal. Part 1: a visualization study. Lasers Surg Med. 2009;41(7):514-519. doi: 10.1002/Ism.20798

23. De Moor RJ, Blanken J, Meire M, Verdaasdonk R. Laser induced explosive vapor and cavitation resulting in effective irrigation of the root canal. Part 2: evaluation of the efficacy. Lasers Surg Med. 2009:41(7):520-523. doi: 10.1002/lsm.20797.

24. de Groot SD, Verhaagen B, Versluis M, Wu MK, Wesselink $P R$, van der Sluis LW. Laser-activated irrigation within root canals: cleaning efficacy and flow visualization. Int Endod J. 2009;42(12):1077-1083. doi: 10.1111/j.13652591.2009.01634.x.

25. Spangberg L. Instruments, materials, and devices. In: Cohen S, Burns RC. Pathways of the pulp. 7th ed., St Louis, MO: Mosby Inc., 1998.

26. Doğan H., Qalt S. Effects of chelating agents and sodium hypochlorite on mineral content of root dentin. J Endod. 2001;27(9):578-580.

27. Boutsioukis C, Gogos C, Verhaagen B, Versluis M, Kastrinakis E, Van der Sluis LW. The effect of apical preparation size on irrigant flow in root canals evaluated using an unsteady Computational Fluid Dynamics model. Int Endod J. 2010;43(10):874-881. doi: 10.1111/j.1365-2591.2010.01761.x.

28. Boutsioukis C, Verhaagen B, Versluis M, Kastrinakis E, Wesselink PR, van der Sluis LW. Evaluation of irrigant flow in the root canal using different needle types by an unsteady computational fluid dynamics model. J Endod. 2010;36(5):875-879. doi: 10.1016/j.joen.2009.12.026

\section{Sharonit SAHAR-HELFT DMD, Lecturer \\ Department of Endodontics School of Dental Medicine Hebrew University-Hadassah (HUHSDM) Jerusalem, Israel} CII

Dr Sharonit Sahar-Helft is a lecturer in the Department of Endodontics at the Hebrew University-Hadassah School of Dental Medicine in Jerusalem (HUHSDM), Israel. She graduated her dental studies and she got her DMD degree at the "Carol Davilla" University, Bucharest, Romania, in 1991. She went to HUHSDM, where she completed the postgraduate program in the Endodontics in 2000.

From 2000 till today Dr. Sharonit Sahar-Helft has been researching the laser fields and she has published a lot of articles and book chapters. Since 2006 till today Dr Sharonit Sahar-Helft has been Istael's representative at the World Federation Laser Dentistry (WFLD). Since 2013 till today: Head of Israel society for laser in dentistry (ISLD). 2013-2016: Chairperson of the organizing committee of Israel laser in dentistry.

2014-2016: Responsible for the external relations and correspondence of the WFLD Europe division.

Responsible for laser research and cooperation between Israel conferences and other countries.

Currently, Dr. Sharonit Sahar-Helft also works in private practice, limited to endodontics. 


\section{Ouestions}

The smear layer is packed into the dentin tubules at a depth of:

口a. 1. Less than $40 \mu$;

b. Up to $40 \mu$;

c. $1-2 \mu$;

$\square$ d. Only at the infected areas on the root canal.

\section{To remove the smear layer after endodontic preparation you have to:}

$\square$ a. Clean the root canal wall with bigger file in order to remove the smear layer;

b. Use irrigation solution like 17\% EDTA in order to remove the smear layer;

ac. Use all kinds of lasers to remove smear layer;

口d. Use LAI (Laser Activated Irrigation) Er:YAG laser with 17\% EDTA to remove smear layer.

Lasers pulsed infrared cause cavitation-bubbles and pressure waves within the root canal space when combined with irrigants. Which laser you will prefer:

口a. CO2 laser

ab. Er:YAG laser

$\square$ c. Diode laser;

d. Blue laser.

\section{The position of the laser tip inside the root canal is important: chose the correct answer:}

$\square$ a. The irrigation solution can penetrate through the apical constriction when the laser tip was close to the apical area;

b. To have efficient effect the laser tip should be insert till the apical area;

c. You should use the laser tip as much as it penetrates into the root canal;

$\square$ d. You should initiate the laser tip before treatment. 